\title{
AN ANALYSIS OF STUDENTS' ANXIETY AND SELF-EFFICACY IN WRITING AT ENGLISH DEPARTMENT OF HALU OLEO UNIVERSITY
}

\author{
Nur Lena \\ Amir Jaya \\ Mursalim \\ English Department \\ Halu Oleo University
}

\section{Email: nurlena1296@gmail.com}

\begin{abstract}
Anxiety is one of students' problems in writing. Students with high anxiety have enormous impact on their writing outcomes. The purpose of this study was to find out the students anxiety in writing and their self-efficacy categories. This study employed survey design. The sample of this study was the students of the fourth semester in writing III course which consisted of 33 students. The data were collected by using close-ended questionnaire and interview guide. The close-ended questionnaire was analyzed by using SPSS 16 version while interview was analyzed descriptively. The result showed that cognitive anxiety was dominant category of writing anxiety and unity was dominant category of writing self-efficacy experienced by the students.

Keywords: Students Anxiety, Students Self-Efficacy, Writing Performance.
\end{abstract}

Introduction

Writing is one of language skills that should be mastered by students in learning language after listening, speaking, and reading. It is important to master writing because language proficiency of learners is measured by their writing performance. Generally, it is assumed that a person who has a good writing ability automatically has substantial language mastery. Hashemnejad, Zogho, \& Amini (2014) point out that student can show their knowledge in the target language by writing. In other words, if the learners master writing, they are able to sharpen their ability in language aspects such as vocabulary and grammar due to the fact that producing a good writing needs the mastery on language aspects. In the process of writing, learners need components of linguistic. According to Harris (1974), there are five linguistic components of writing namely, content, organization, vocabulary, grammar, and mechanics. 
The learners must be able to apply the five components of writing because good writing contains components of writing. Yet, applying the components of writing is not a simple process. In writing, the learners not only should be able to express their ideas but they must be able to organize their sentences as well.

During writing, it is very possible for learners to experience anxiety (Kara, 2013). Anxiety is defined as the subjective feeling of tension, apprehension, nervous, and worry in writing. In other words, the learners are not able to express their ideas effectively when they feel tension or apprehension in their writing class. This situation happens because they have high anxiety. For example, he/she feels apprehension whenever the teacher reads his or her writing. It happens because the learners have high anxiety and low self-efficacy in writing. Subsequently, it can affect their achievement in their writing class. According to Marra in Tupang (1956), writing anxiety occurs because of language anxiety complexity in general and complexity in writing. In response to the idea that anxiety can affect students' achievement in class, several studies done to investigate the issue. Zhang (2011) in the study about ESL writing anxiety among Chinese English major found that the most common type of writing experienced by her participants was Cognitive Anxiety.

Self-efficacy is an individual's confidence in his/her ability to successfully perform a particular task. It affirms that individual who judges themselves competent in performing certain tasks are more expected to be competent of doing the particular task. In writing, a strong sense of self-confidence in the writing task is called as writing self-efficacy. Students may feel improved to write when they have self-belief or self-confidence in their ability to write. However, writing is the most difficult skill to be learned. As it seems, the problem in which EFL learners have is difficulty in writing. Consequently, teachers should be able to encourage students' cognitive, behavioral, and motivational engagement by enhancing students' self-efficacy. 
Students with a high level of self-efficacy have a high level of selfconfidence and they believe that they can organize the learning environment in a conducive to their learning. The learner with a high self-efficacy feel confident about finding the solution to a problem because she or he has created an idea to problem solving that has been accomplished in the past. They believe that their own skill will be better when they work more. Those who have a high confidence in the writing ability are considered as people with high self-efficacy or having a positive sense of self when it comes to writing.

In relation to the aforementioned issue, this study tries to investigate writing anxiety and writing self efficacy experienced by EFL students.

Literature Review

Students Anxiety in Writing

Anxiety is one of the factors that affect the process of learning. When students perform activities that require productive skills, they experience considerable amount of anxiety (Zhang, 2011). As a productive skill, writing has been viewed as a demanding process. Writing anxiety occurs because of language complexity in general and complexity of writing as a skill in particular. Moreover, Kean et al. in Kara (2013) states that the effect of writing anxiety is most likely to be manifested when the apprehensive writer composes under time pressure. It means that the effect of writing anxiety can happen when the students write under time pressure.

Daly (1978) states that writing anxiety is "a general avoidance of writing and of situations perceived by the individuals to potentially require some amount of writing accompanied by the potential for evaluation of that writing". It means that writing anxiety is the situations felt by the students when in the process of evaluation they choose to avoid writing class. Moreover, Thompson in Atay and Kurt (2007) states that writing anxiety is "far of the writing process that outweighs the projected gain from the ability to write". It happens because students have high sense of worry. This statement is in accordance with the statement by Hassan (2001) "students with low anxiety have better quality 
compositions writing than their high anxiety counterparts". In other words, writing anxiety negatively influences the quality of students' composition.

Cheng (2004) divides categories of writing anxiety into three categories namely cognitive anxiety, avoidance behavior, and somatic anxiety. Cognitive anxiety refers to negative expectations, preoccupation with performance and concern with others' perception. How the students compose their writing can be highly influenced by expectations from the other students or teacher. Somatic anxiety refers to one perception of the psychological effect of the anxiety experienced such as nervousness and tension. Sometimes students are feeling nervous and in high tension when they are under time constraint. The last is avoidance behavior is a type of anxiety where the students avoid writing. This is a behavior which affects the anxiety experience. It is the most dangerous type of writing anxiety because the students avoid writing.

There are some possible causes of writing anxiety proposed by some experts. Firstly, Hassan in Tupang (1956) argues that writing anxiety can be caused by poor skill development, inadequate role models, lack of understanding in the composing process, and authoritative, teacher centered, and product-based model of teaching. Secondly, Hyland in Zhang (2011) states that ESL writers often carry the burden of learning to write in English. The burden can be identifying language difficulties, such as an inadequate grasp of vocabulary and grammar. Those causes can be main problems with English writing and as the main sources of frustration being unable to express their idea.

Students Self-efficacy in Writing

Pajares and Jonson (1993) state that writing self-efficacy is individuals' judgment of their competence in writing, especially their judgment of their ability to write different writing tasks and their control of unreliable composition, usage and mechanical skills. According to Hashemnejad et al (2014) writing self-efficacy means students' belief about their ability to perform written English task successfully. It refers to the students' belief about their 
competence in writing. This statement is supported by Bandura (1997) who states that "Students belief about their competence in performing task is very important because if students do not believe that's having negative impact and students with high self-efficacy having positive impact"

Erkan (2013) argues that self-efficacy in writing is classified into five categories, namely content, design, unity, accuracy, and punctuation. Content refers to individual belief about her/his ideas in expressing their writing. The ideas are complete and clear and the details are relating to the idea. It means that the ideas must be relevant. So the readers can understand easily. Design refers to individual belief about the content and generic structure of writing. The content and generic structure is arranged with proper connectives. It means that when the students write the content and generic structure, it must be connecting. Unity refers to individual belief in connecting word or sentence into paragraph. It means that when the students write, he/she believes that they can connect a word or sentence into good paragraph. Accuracy refers to individual belief about agreement, use of tenses, etc. It means that when students write they believe that the grammatical used is appropriate with the sentence or without making grammatical errors. Punctuation refers to individual belief about the use of punctuation correctly and frequent errors of punctuation.

Bandura (1977) states that self-efficacy could be generated from a learners' though when he/she interprets the information which is derived from four sources. The first and the most powerful source which influences selfefficacy is mastery experience. In the context of L2/FL learning, it refers to learners' previous successes in a certain area of abilities/skills. Learners' grades or scores in previous language courses can heighten or lower their confidence in doing a related language task. The second source, vicarious experience, is when learners observe language performance of others and compare it to their own. According to self-efficacy theory (Bandura, 1977), the most dominant form of vicarious experience is when doing a task, learners will 
generate the beliefs that "if he/she can do, so can I". Thirdly, social persuasion, helps learners to form personal efficacy when the comment or feedback they receive is interpreted in a positive way. Learners who positively perceive feedback and they tend to regulate themselves in terms of strategies until they find the strategies which work on them. The fourth is emotional state. If refers to anxiety or fear that students encounter when they need to perform certain task that they perceive to be out of control.

Self-efficacy has powerful effects on learning and motivation, (Bandura, 1982); Self-efficacy influences the goals that students choose for themselves. Students with low levels of self-efficacy tend to set relatively low goals for themselves. On the contrary, an individual with high self-efficacy is likely to set high personal goals. Self-efficacy influences learning as well as the effort that people exert on the job. Students with high self-efficacy generally work hard to learn how to perform new tasks because they are confident that their efforts will be successful. Students with low self-efficacy may exert less effort when learning and performing complex tasks because they are not sure that the effort will lead to success.

Research Method

This study employed survey design. The population of this study was 112 students. Those students were in the fourth semester pursuing writing III course at English Department of Halu Oleo University. Of the 112 populations, 3333 students were selected as the sample of this study. The samples were selected by using purposive and snowball sampling.

The data were collected by using close-ended questionnaire which was adopted from Cheng (2004). The questionnaire was tried out to students who were not belonging to the sample of this study. The questionnaire for writing anxiety consisted of three categories, namely cognitive anxiety, somatic anxiety and avoidance behavior. There were six items dealing with cognitive anxiety, four items dealing with somatic anxiety and four items dealing with avoidance behavior. Writing self-efficacy consisted of five categories consisting of 14 items; content, design, unity, accuracy and punctuation. While interview data 
were gathered using interview guide consisting of 2 questions. The interview was assigned to five participants who were selected randomly.

The close-ended questionnaire was analyzed by using SPSS 16 version while interview was analyzed descriptively. In analyzing the data of questionnaire, the researcher analyzed about frequency, percent and mean score of the data.

Findings

The findings consist of students' writing anxiety and students' writing self efficacy.

Students' Anxiety in Writing

The following table presents data about students' anxiety in writing.

Students' Anxiety in Writing

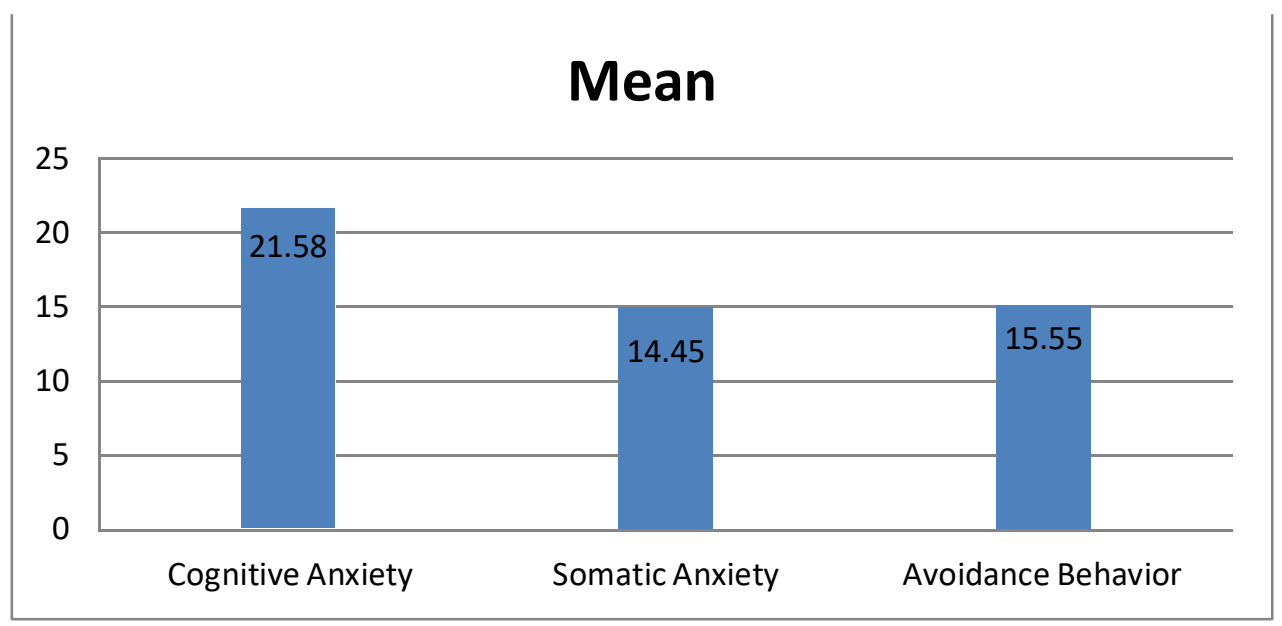

Based on the chart above, it could be seen that students felt high anxiety in cognitive anxiety (21.58). Students were worried about others' perceptions (teacher and students), such us feeling afraid if they got bad score. They also were worried about what other people think about their writing compositions. It happens because students' had low self-efficacy. It means that students' confidence in this aspect needs to be increased. Moreover, avoidance behavior was moderate category (15.55). Then, students felt low anxiety in somatic anxiety (14.45). It means that students can overcome their anxiety.

Students Self-Efficacy in Writing

The following table presents data about students' self efficacy in writing. 


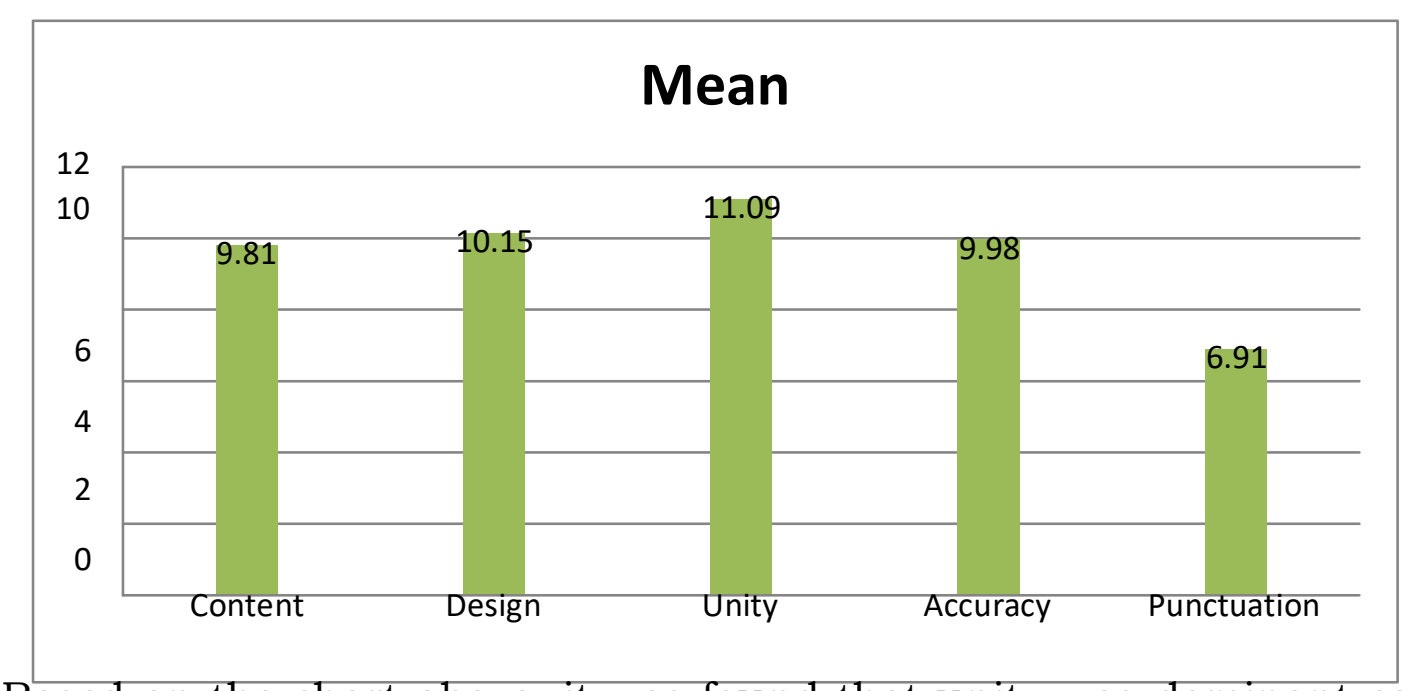

Based on the chart above, it was found that unity was dominant category of students' self-efficacy in writing (11.09). It means that students had high self-efficacy in that demand. They believed that they could organize their compositions well. Moreover, students had low self-efficacy in category punctuation (6.91). Students' belief in using punctuation marks was very less. It means that students' belief about their confidence in this category needs to be increased by themselves or other people (teacher).

Concerning with the finding of interview, the finding is as follows:

\section{Student 1}

She explained that she ever faced anxiety in writing process. When the researcher asked the reason of feeling anxious in writing process, she stated that she felt worry when her English compositions were worse than others. Several factors affected her when writing process such as lack of selfconfidence. In relation to writing self-efficacy, she believed that although she made mistakes in writing process, she tried to write well.

\section{Student 2}

When the researcher asked, she explained that she was worried about her English compositions. She was afraid of getting a very poor grade. She stated that it was caused by some factors such as lack of comprehension about grammar. It caused her feeling anxious. It might happen because she had lack of self-confidence especially in writing process. Related to writing self-efficacy, 
she believed that she can connect words become sentences into good paragraph.

\section{Student 3}

She said that she was worried about what other people would think about her English compositions. It happened because she felt that her ability in writing was less especially lack of vocabularies and the capability about grammar. It was caused by lack of self confidence about her ability in writing process. In relation to writing self-efficacy, she stated that sometimes she made mistakes in writing process but she tried to write good compositions. She believed with her ability in writing.

\section{Student 4}

She explained that in writing process, she experienced anxiety. When the researcher asked, she stated that her thoughts became jumbled when she wrote in English compositions under time constraint. She was afraid when her English compositions had been finished. It made her cannot think the ideas quickly so when the teacher gave time to do the assignment, she often felt anxious. It happened because of having lack of self-confidence about her ability especially in writing. In relation to writing self efficacy, she said that she can use grammar correctly.

\section{Student 5}

She stated that she often felt panic when she wrote in English compositions under time constraint. She is type of people who like to work in the last time. So, when the teacher gave time to finish the assignment, she felt very anxious. Although it was so, she tried to write in good sentence or paragraph. Related to the writing self-efficacy, she believed that can use punctuation in writing compositions appropriately without making mistakes.

\section{Discussion}

The findings indicate that students felt high anxiety in cognitive anxiety. It is in line with Tupang (1956) study 'who found that cognitive anxiety was the most common type of writing anxiety experienced by students. Students faced 
cognitive anxiety when they were concern too much with negative expectation or others' expectation. They felt worry and uneasy when they knew that their writing compositions would be evaluated. Writing anxiety negatively influenced the quality of students' compositions (Hassan, 2001). It means that students with low anxiety have better quality writing than their high anxiety counterparts. Moreover, students felt anxious in avoidance behavior, such us students usually do the best to avoid mistake in writing English compositions. Writing anxiety as "a general avoidance of writing and of situations perceived by the individuals to potentially require some amount of writing accompanied by the potential for evaluation of that writing" (Daly, 1978).

The last category of students' anxiety is somatic anxiety. This category was the lowest anxiety experienced by the students in writing, such as students became jumbled when they wrote in English compositions under time constraint. It is in line with the statement by Thompson in Atay and Kurt (2007) 'Writing anxiety is a fear of the writing process that outweighs the projected gain from the ability to write".

Concerning writing self-efficacy, the findings indicate that unity was dominant category experienced by students in writing. Students with high selfefficacy have positive impact on their writing because they are able to plan effectively and successfully in completion of a task (Bandura, 1982). Such students believe that they can organize their writing compositions very well, they can connect some words to be a good sentence.

Moreover, students felt low self-efficacy in punctuation. Students had low self-efficacy about their ability in using punctuation. Students with low selfefficacy can influence the goals in learning process especially in writing for themselves. Students with low self-efficacy tend to set relatively low goals.

Conclusion

Cognitive anxiety was dominant category and particular category experienced by students in writing. The result showed that students experienced anxiety such us students were worried about their writing composition if they knew that they would be evaluated, students were worried 
about getting a very poor grade and they were worried about what other people think about their writing compositions. Moreover, unity was dominant category in self-efficacy in writing. Students had high self-efficacy in organizing their writing compositions. It is recommended for the writing teachers to be creative in teaching writing, use various methods and have innovation to teach the students. For students, they have to improve their knowledge about how to write good compositions and build a good confidence.

\section{References}

Atay, D. \& Kurt, G. (2007). The Effect of Peer Feedback on the Writing Anxiety of Prospective Turkish Teachers of EFL. Journal of Theory and Practice in Education, 3 (1), 12-23. Turkish: Marmara University.

Bandura. A. (1997). Social Learning Theory. New York: General Learning Press.

Bandura, A. (1977). Social Cognitive Learning Theory. Retrieved January $28^{\text {th }}$, 2018, from https:// principlesoflearning.wordpress.com/dissertation/chapter-3literature-review-2/the-social-perspective/social-cognitive-learningrheory-albert-bandura-1977/.

Bandura, A. (1982). Self-efficacy Mechanism in Human Agency. American Psychologist, 37 (2): 122-147.

Cheng, Y. S. (2004). A Measure of Second Language Writing Anxiety: Scale Development and Preliminary Validation. Journal of Second Language Writing, 13(4): 313-335.

Daly, J. (1978). Writing Apprehension and Writing Competency. Journal of Educational Research, 72: 10-12. Retrieved on March 6th, 2018 from http://dx.doi.org/10.1080/00220671.1978.10885110.

Erkan, Y. (2013). Effect of Cross-Culture E-mail Exchange on Self-Efficacy in Writing. Cukurova University.

Firawati (2016). Analysis of Students Anxiety in Learning English at Class VIII.2 of SMP NEGERI 10 Kendari. Kendari: Unpublished Thesis.

Harris, D. P. (1974). Testing English as a Second Language. Tata McGraw-Hill Book Company: New York.

Hashemnejad, F., Zogho, M. \& Amini, D. (2014). The Relationship between SelfEfficacy and Writing Performance Across Genders. Journal of Theory and Practice in Language Studies, Vol. 4. Retrieved on January $28^{\text {th }}$ 2018

from 
http://www.ojs.academypublisher.com/index.php/article/download.../ 9335.

Hassan (2001). The Effect of Peer Feedback on the Writing Anxiety of Prospective Turkish Teachers of EFL. Journal of Theory and Practice in Education, 2(2): 12-23. Turkish: Marmara University.

Kara, S. (2013). Writing Anxiety: A Case Study on Students' Reasons for Anxiety in Writing Classes. Anadolu Journal of Educational Sciences International, 3(1).

Pajares, M. F and Johnson, M. J. (1993). Confidence and Competence in Writing: The Role of Self-efficacy, Outcome Expectancy, and Apprehension. Paper presented at the Annual Meeting of American Educational Research Association (Atlanta, GS, April 12-16, 1993). Retrieved March 6th 2018 from files.eric.ed.gov/fulltext/ED358474.pdf.

Tupang, K. S. (1956). Investigating Students Writing Anxiety: A Study at English Teacher Education of Satya Wacana Christian University. Indonesia: Wacana Christian University.

Zhang, H. (2011). A Study on ESL Writing Anxiety Among Chinese English Majors- Causes, Effects and Coping Strategies for ESL Writing Anxiety. Sweden: Kristianstad University. 